\title{
A model for estimating endogenous protein flows in the gastrointestinal tract of ruminants*
}

\author{
A.G. Assis', J. France ${ }^{2, * *}$, J. Dijkstra ${ }^{3,5}$ and D.M. Veira ${ }^{4}$
}

${ }^{2}$ Embrapa, Centro Nacional de Pesquisa de Gado de Leite.

Rua Eugenio do Nascimento 610 ,

Dom Bosco - Juiz de Fora, MG, 36038-330 Brazil

${ }^{2}$ Institute of Grassland and Environmental Research, North $W_{y k e}$

Devon EX2O 2SB, United Kingdom

"Wageningen Institute of Animal Sciences, Animal Nutrition Group

Marijkeweg 40,6709 PG Wageningen, The Netherlands

${ }^{4}$ University of Manitoba, Department of Animal Science

Winnipeg, Manitoba R3T 2N2, Canada

(Received 28 July 1997: accepted 19 August 1997)

\begin{abstract}
A simulation model was built to represent the kinetics of endogenous-protein nitrogen (EPN) in the gastrointestinal tract (GIT) of ruminants. The GIT is split into three compartments, namely: stomach, smal! intestine and large intestine. The model contains three pools corresponding to these compartments and utilizes two types of source (secretions and inflow) and exit (absorption and passage) for EPN. Parameter values are set based on relevant data from the literature. According to model predictions, proportion of ElPN in the total $N$ llow increases as $C P$ content of the diet and nitrogen intakc decrease. On extremely low protein diets, E.PN may represent 43,66 and $92 \%$ of the total $\mathbf{N}$ in the abomasal, ileal and faecal contents, respectively. The model can contribute to improve knowledge on nitrogen recycling as well as to account for endogenous protein losses in the calculation of maintenance requirements.
\end{abstract}

KEY WORDS: nitrogen recycling, endogenous protein, kinetics, ruminants, simulation model

* The project was partially supported by the Brazilian Research Council (CNPq) through a post - doctoral fellowship for the first author. The research of J. Dijkstra has been made possible by a fellowship of the Royal Netherlands Academy of Arts and Sciences.

** Corresponding author: Dr J.France 


\section{INTRODUCTION}

Endogenous proteins produced along the digestive tract of ruminants are important sources of nitrogen recycling and contribute significantly to the duodenal and ileal non-ammonia nitrogen (NAN) flows (MacRae et al., 1979; van Bruchem et al., 1985a, 1989). In a recent review, Tamminga et al. (1995) discussed the consequences for protein deposition and $\mathrm{N}$ losses to the environment. In some cases, endogenous protein $\mathrm{N}$ absorbed from the small intestine may be up to four times the amount of digesta $\mathrm{N}$ flowing from the abomasum (Egan et al., 1986). Although some attempts have been made to quantify endogenous protein nitrogen (EPN) sources (e.g., Ørskov ct al., 1986; Hart and Leibholz, 1990; Voigt et al., 1994), the majority of digestion and metabolism studies do not account for all sorts of EPN in the whole alimentary tract of ruminants, and their consequences in the current feeding systems. According to Satter and Dhiman (1995), most of the discrepancy between the American (NRC, 1989) and British (AFRC, 1992) protein systems for dairy cows is related to the maintenance requirements, especially in the estimates of endogenous protein losses.

The objectives of the present study are to represent, by means of a mathematical model, flows of endogenous protein through the ruminant alimentary tract, and to assess their implications to the protein nutrition of dairy cows.

\section{MATERIAL AND MLIHODS}

\section{Background of the model}

In ruminants, recycling of $\mathrm{N}$ can occur through the following processes: (i) intra- and inter-cellular cycling, with reutilization of amino acids in the cells; (ii) urea cycling, with end products of amino and nucleic acid catabolism reentering the GIT via saliva or diffusion through the gut wall; and (iii) protein cycling, with amino acids and proteins in secretions and sloughed epithelial cells from the GIT being digested, absorbed and reutilized (Egan et al., 1986). The present model deals only with this last source of $\mathrm{N}$ recycling.

Studies have indicated that EPN entering the reticulo-rumen contributes to the peptides, amino acids, and ammonia drawn on by microorganisms (Egan et al., 1986), but some escape microbial degradation and flow on in the digesta. Thus, EPN entering the abomasum and the small intestine in the digesta and also in secretions and cell debris will contribute to amino acid absorption. In the large intestine, a fraction of EPN is incorporated into caecal bacteria and another fraction will be lost as endogenous faecal N (EFN) with absorption of some ammonia (Swanson, 1982). 
The nutritional significance of EPN changes with the rate and site of secretions and the amount of exogenous protein supply, but quantitative measurements have always presented difficulties (Tamminga et al., 1995). Kennedy and Milligan (1980) have estimated EPN inputs into the forestomach and abomasum of sheep at 8.1 to $10.8 \mathrm{~g} / \mathrm{d}$, or 400 to $540 \mathrm{mg} / \mathrm{kg}$ of metabolic weight $\left(\mathrm{W}^{0.75}\right)$. The larger values at the higher level of feed intake are consistent with increased abrasion and sloughing of ruminal epithelium. Flow of EPN to the abomasum was about $5 \mathrm{~g} / \mathrm{kg}$ dry matter intake (DMI) of which $1 \mathrm{~g}$ was from saliva, $1 \mathrm{~g}$ from gastric secretions and the remainder due to the sloughing of ruminal epithelium (Kennedy and Milligan, 1980). Hart and Leibholy (1990) have reported values for cattle from 3.3 to $9.4 \mathrm{~g} \mathrm{EPN} / \mathrm{kg}$ DMI flowing into the abomasum.

At the intestinal level, there is evidence that fibre increases mucosal cell losses and secretion of enzymes and mucoproteins (Żebrowska and Kowalczyk, 1991). This is consistent with previous findings that the non-protein dry matter flow may determine the release of EPN through the small intestine (van Bruchem et al., 1989), with endogenous sources contributing up to $65 \%$ of ileal protein flow (van Bruchem et al., 1985a). Other studies have shown that the large intestinal wall adds $\mathrm{N}$ to digesta in the form of mucins and sloughed epithelial cells, and that faecal excretion of these constituents was stimulated by high-fibre diets (Mason, 1984). Furthermore, $\mathrm{N}$ additions between the ileum and rectum were reported to originate partially from microbial incorporation of ammonia derived from EPN, which is mostly excreted as EFN (Dixon and Nolan, 1983).

\section{Structure of the model}

In the present study, EPN kinetics is represented by a dynamic, compartmental model (Figure 1), which has been already described briefly by Assis et al. (1993). In this model, for reasons of simplicity and of lack of quantitative data, the GIT is split into three compartments, namely: stomach - comprising rumen, reticulum, omasum and abomasum; small intestine - duodenum, jejunum and ileum; and large intestine - caecum, colon and rectum. For the same reasons, secretions and cell debris are assumed to be directly related to the level of DMI, likely the most preponderant factor affecting production of EPN in the gut (Kennedy and Milligan, 1980; Swanson, 1982; Hart and Leibhol<, 1990). In each compartment, a fraction of EPN is subject to degradation and absorption while another fraction flows out into the next compartment. In the stomach, ammonia originating from ruminal degradation of endogenous protein will become part of the ammonia pool, which will be either incorporated into microbial protein or absorbed through the ruminal wall. In the small intestine, a fraction of EPN is digested and absorbed as amino acids and the remainder enters the large intestine. 


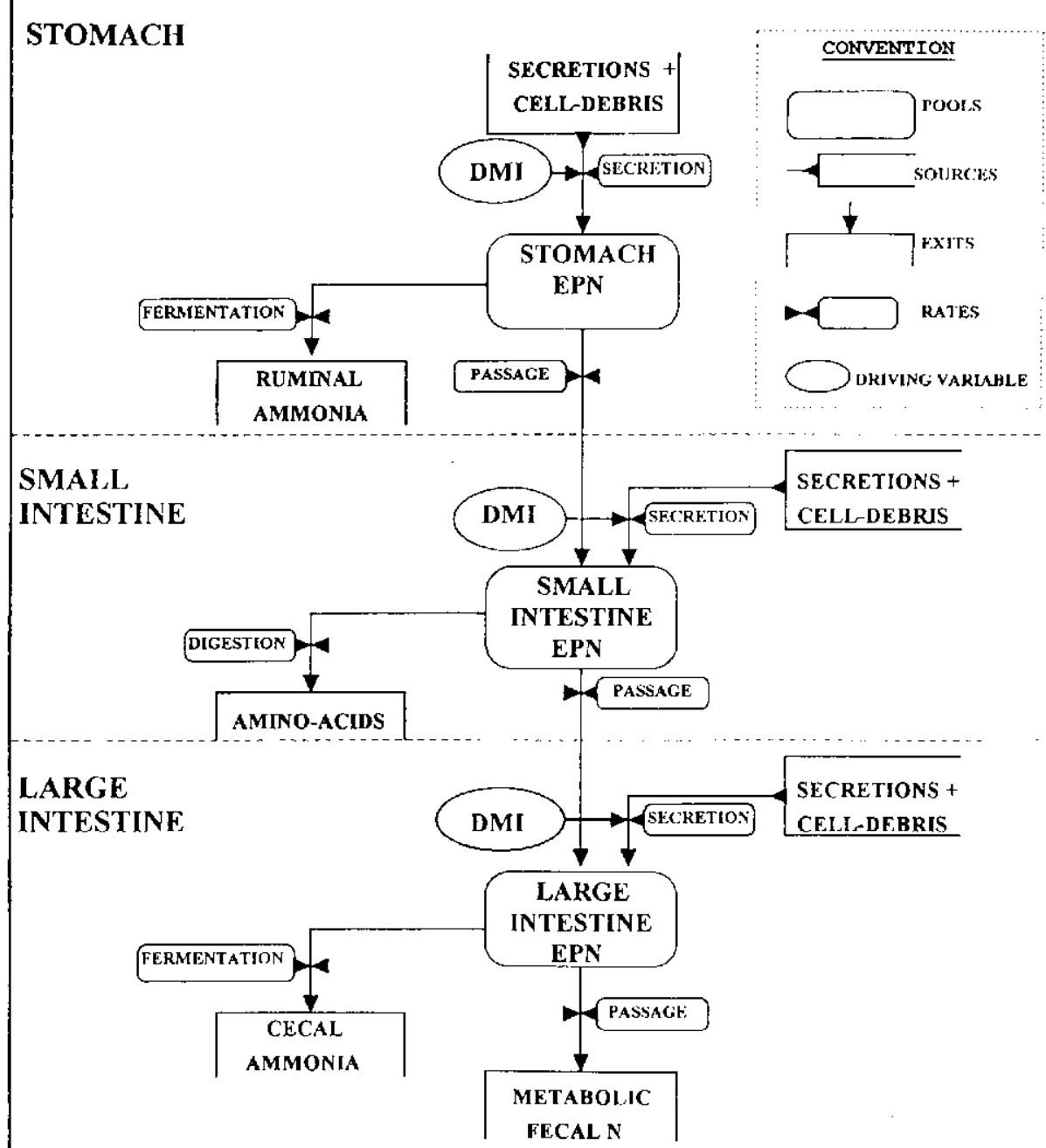

Figure 1. Flow-diagram representing endogenous-protein nitrogen (EPN) kinetics in the gastrointestinal tract of ruminants

In this final compartment, some EPN is degraded by caecal bacteria; the released ammonia is absorbed and the undigested fraction of EPN excreted as EFN.

The model contains three pools (state variables) for the accumulation of EPN, which correspond to the three compartments: stomach $\left(Q_{1}, m g N\right)$, small intestines $\left(\mathrm{Q}_{2}, \mathrm{mg} \mathrm{N}\right)$, and large intestines $\left(\mathrm{Q}_{3}, \mathrm{mg} \mathrm{N}\right)$. All fluxes in the model are in units $\mathrm{mg} \mathrm{N} / \mathrm{h}$. The stomach EPN has one input $\left(\mathrm{F}_{10}\right)$, the secretions plus cell 
debris. Outputs from the pool are the degradation and absorption of EPN $\left(\mathrm{F}_{01}\right)$ and the passage of EPN $\left(\mathrm{F}_{21}\right)$. The small intestinal EPN has inputs from the stomach $\left(\mathrm{F}_{21}\right)$ and the secretions plus cell debris $\left(\mathrm{F}_{20}\right)$. Outputs from the pool are the degradation and absorption of EPN $\left(\mathrm{F}_{02}\right)$ and the passage of EPN $\left(\mathrm{F}_{32}\right)$. Similarly, the large intestinal FPN has inputs from the small intestines $\left(\mathrm{F}_{32}\right)$ and the secretions plus cell debris $\left(\mathrm{F}_{30}\right)$, and outputs from the pool are the degradation and absorption of EPN $\left(\mathrm{F}_{03}\right)$ and the passage of EPN into the faeces $\left(F_{f 3}\right)$. The change of state variable with time is described by the differential equations:

$$
\begin{aligned}
& \mathrm{dQ}_{1}=\mathrm{F}_{10}-\mathrm{F}_{01}-\mathrm{F}_{21} \\
& \mathrm{dQ}_{2}=\mathrm{F}_{20}+\mathrm{F}_{21}-\mathrm{F}_{02}-\mathrm{F}_{32} \\
& \mathrm{dQ}_{3}=\mathrm{F}_{30}+\mathrm{F}_{32}-\mathrm{F}_{02}-\mathrm{F}_{13}
\end{aligned}
$$

General equations used for calculating flows of EPN through the alimentary tract are based on principles of first order kinetics and mass conservation as follows:

$$
\mathrm{F}_{\mathrm{ji}}=\mathrm{k}_{\mathrm{pi}} \mathrm{Q}_{\mathrm{i}}
$$

for passage from pool $\mathrm{i}$ into pool $\mathrm{j}$ and $\mathrm{k}_{\mathrm{pi}}$ is fractional passage rate $\left(\mathrm{h}^{-1}\right)$, and

$$
\mathrm{F}_{\mathrm{oi}}=\mathrm{k}_{\mathrm{di}} \mathrm{Q}_{\mathrm{i}} \mathrm{C}_{\mathrm{M}}
$$

for degradation and absorption within stomach $(i=1)$ and large intestines $(i=3)$, $\mathrm{C}_{\mathrm{M}}$ is the microbial concentration ( $\mathrm{mg} \mathrm{N} / 100 \mathrm{ml}$ ) and $\mathrm{k}_{\mathrm{di}}$ is fractional degradation and absorption rate $\left(\mathrm{h}^{-\mathrm{i}}\right)$, and

$$
\mathrm{F}_{\mathrm{oi}}=\mathrm{k}_{\mathrm{di}} \mathrm{Q}_{\mathrm{i}}
$$

for degradation and absorption within the small intestines $(i=2)$, and

$F_{i o}=P_{i} D M I$

for secretions plus cell debris to pool ${ }_{i}, P_{i}$ is the EPN per unit DMI (mg N/g DMI).

The computer program is written in Continuous Simulation Modeling Program - CSMP (IBM 1975), using a PC version adapted by Jansen et al. (1988). Each pool is updated every $0.0 \mathrm{l}$ h by the Adams method of integration.

\section{Parameter values}

All values for model parameters were taken or derived from literature data. Rate of EPN secretions and cell debris for the stomach is an average figure from sheep data (Kennedy and Milligan, 1980; Egan et al., 1986); for the small intestine it is a mean value from cattle and sheep (Swanson, 1982; Żebrowska and Kowalczyk, 1991); and for the large intestinc it is from sheep (Egan ct al., 1986). A series of calculations had to be undertaken to estimate the $\mathrm{k}_{\mathrm{d}}$; of each pool i. In this calculation, first order kinetics and steady state were assumed so that the amount of EPN entering each pool is equal to the amount absorbed across the 
compartment wall plus the amount flowing out into the next pool. Information on daily secretions and flows of EPN for the stomach and large intestine were taken from the literature (Stallcup et al., 1975; Kennedy and Milligan, 1980; Egan et al., 1986; Hart and Leibholz, 1990) and converted to a body-weight unit (mg EPN/kg $\mathrm{W}^{0.75}$ ). Values of EPN flow for the small intestine were based on the extent of EPN degradation in this site, which can be considered similar to that of microbial protein (Żebrowska and Kowalczyk, 1991), and assumed equal to 0.80 .

TABLE 1

Main parameters used in the model of endogenous-protein nitrogen (EPN) kinetics

\begin{tabular}{llllc}
\hline Parameter & \multicolumn{1}{c}{ Description } & Value & Unit & Ref. $^{{ }^{a}}$ \\
\hline $\mathrm{P}_{1}$ & EPN originated from the stomach (ST) & $56 \times 10^{-1}$ & $\mathrm{mg} \mathrm{N} / \mathrm{g} \mathrm{DMI}$ & 1 \\
$\mathrm{k}_{\mathrm{p}, 1}$ & Fractional passage rate of EPN from ST & $42 \times 10^{-3}$ & $\mathrm{~h}^{-1}$ & 2 \\
$\mathrm{k}_{\mathrm{d}, 1}$ & Fractional degradation rate of EPN in ST & $57 \times 10^{-6}$ & $100 \mathrm{ml} / \mathrm{mg} \mathrm{N} / \mathrm{h}$ & 3 \\
$\mathrm{C}_{\mathrm{M}}$ & Microbial concentration in the reticulo-rumen & $29 \times 10^{1}$ & $\mathrm{mg} \mathrm{N} / 100 \mathrm{ml}$ & 4 \\
$\mathrm{P}_{2}$ & EPN originated from the small intestine (SI) & $80 \times 10^{-1}$ & $\mathrm{mg} \mathrm{N} / \mathrm{g} \mathrm{DMI}$ & 5 \\
$\mathrm{k}_{\mathrm{p}, 2}$ & Fractional passage rate of EPN from SI & $22 \times 10^{-2}$ & $\mathrm{~h}^{-1}$ & 2 \\
$\mathrm{k}_{\mathrm{d}, 2}$ & Fractional degradation rate of EPN in SI & $88 \times 10^{-2}$ & $\mathrm{~h}^{-1}$ & 6 \\
$\mathrm{P}_{3}$ & EPN originated from the large intestine (LI) & $13 \times 10^{-1}$ & $\mathrm{mg} \mathrm{N} / \mathrm{g} \mathrm{DMI}$ & 7 \\
$\mathrm{k}_{\mathrm{p}, 3}$ & Fractional passage rate of EPN from LI & $10 \times 10^{-2}$ & $\mathrm{~h}^{1}$ & 2 \\
$\mathrm{k}_{\mathrm{d}, 3}$ & Fractional degradation rate of EPN in LI & $57 \times 10^{-6}$ & $100 \mathrm{ml} / \mathrm{mg} \mathrm{N} / \mathrm{h}$ & 8 \\
$\mathrm{C}_{\mathrm{M}}$ & Microbial concentration in the caecum & $12 \times 10^{-1}$ & $\mathrm{mg} \mathrm{N} / 100 \mathrm{ml}$ & 9 \\
\hline
\end{tabular}

${ }^{a}$ References:

1. mean value from Kennedy and Milligan (1980) and Egan et al. (1986)

2. O'Connor et al. (1984)

3. calculated value using data from Kennedy and Milligan (1980), Egan et al. (1986) and Hart and Leibholz (1990)

4. calculated value using data from van Soest (1982)

5. mean value from Swanson (1982) and Żebrowska and Kowalczyk (1991)

6. calculated value using data from Żebrowska and Kowalczyk (1991)

7. mean value from Egan et al. (1986)

8. calculated value using data from Stallcup et al. (1975) and Egan et al. (1986)

9. calculated value using data from Dixon and Nolan $(1982,1983)$

The size of EPN pools was calculated using equation 4, with flow data from the quoted sources, and passage rates of digesta from O'Connor et al. (1984). The calculated values of pool sizes and the daily amounts of the degraded fraction of EPN were used in equations 5 and 6 to estimate the rate of degradation and absorption of EPN for each digestion site. In equation $5, \mathrm{C}_{\mathrm{M}}$ was held constant at 290 and $120 \mathrm{mg} \mathrm{N} / 100 \mathrm{ml}$ of ruminal and caecal contents, respectively (Dixon and Nolan, 1982, 1983; Van Soest, 1994). The secretion and cell debris is expressed in $\mathrm{mg} \mathrm{N} / \mathrm{kg}$ DMI. Thus, DMI is the main driving variable and the only external input to the model. The values of the main parameters, shown in Table 1 , were held constant for testing model behaviour. 


\section{Test of the model}

Due to the lack of independent data on EPN flows through the GIT of ruminants, predictive performance of the model could not be evaluated. Nevertheless, in order to test the model for consistency, predictions of EPN flows, expressed in $\mathrm{mg} \mathrm{N} / \mathrm{kgW}^{0.75}$, were compared, on the same basis, to data of total $\mathrm{N}$ flows reported in the literature for the three sites of the GIT. Sets of $\mathrm{N}$ flow data were taken from digestion trials using diets with low-, medium- or high-protein contents. These trials were carried out with fistulated steers fed diets based on either fresh chopped sugar canc (Oliveira, 1990; Matos, 1991) or lucerne hay plus maize silage (Cecava et al., 1990). Crude protein contents of sugar cane diets were increased by adding urea up to $1.5 \%$ on a fresh weight basis.

Because little information on microbial concentration is available for ruminants fed different types of diet, CM in stomach and large intestine was held constant as previously described. However, in order to analyse the relevance of their accuracy to model performance, a sensitivity test was carried out, varying both constants by $\pm 25 \%$ on all treatments.

\section{RESULTS}

The model was not sensitive to changes in the parameter values describing microbial concentration $\mathrm{C}_{\mathrm{M}}$ in the stomach and the large intestinc. EPN predictions showed only a marginal variation $(3$ to $7 \%$ ) when parameter values departed from the prescribed values $(290$ and $120 \mathrm{mg} \mathrm{N} / 100 \mathrm{ml}$ ) by $\pm 25 \%$. Therefore, predicted values for EPN flows in Table 2 are the result of simulations with the values listed in Table 1.

In order to compare model predictions with literature data, all predicted and reported values were converted to a metabolic weight $\left(\mathrm{W}^{0.75}\right)$ basis. Mean values of DMI from the digestion trials (Table 2) varied from 35.2 to $87.4 \mathrm{~g} /\left(\mathrm{kg} \mathrm{W}^{0.75} / \mathrm{d}\right.$ ), but with an uneven pattern along the line of the dietary $\mathrm{CP}$ content.

Abomasal FPN flows predicted by the model (Table 2) varied from 141 to 351 $\mathrm{mg} \mathrm{N} /\left(\mathrm{kg} \mathrm{W}^{0.75} / \mathrm{d}\right)$, but its proportion to total $\mathrm{N}$ flows decreased as level of $\mathrm{CP}$ and $\mathrm{N}$ intake increased. At the ileum, predicted values of EPN (Table 2) increased from 84 to $210 \mathrm{mg} \mathrm{N} /\left(\mathrm{kgW}^{0.75} / \mathrm{d}\right)$ with an increase of dietary $\mathrm{CP}$ content from 18 to $159 \mathrm{~g} / \mathrm{kg}$ DM. Conversely, proportion of EPN in the total $\mathrm{N}$ flow at this site decreased markedly at the highest level of CP in the diet.

In the present study, excretion of endogenous $\mathrm{N}$ via faeces is treated as flow of EPN at the rectum, or EFN. Rectal EPN flows (Table 2) varied from 122 to 303 $\mathrm{mg} \mathrm{N} /\left(\mathrm{kg} \mathrm{W}^{0.75} / \mathrm{d}\right)$ as CP content of the diet increased up to $159 \mathrm{~g} / \mathrm{kg} \mathrm{DM}$, but its proportion to the total faecal $\mathrm{N}$ reduced markedly. 
TABLE 2

Dry matter and nitrogen (N) intake, total $N$ flow, endogenous protcin $N(E P N)$ predicted by the model and EPN as a percentage of total $\mathrm{N}$ flow at three sites of the gastrointestinal tract of stecrs fed diets with different CP contents

\begin{tabular}{|c|c|c|c|c|c|c|}
\hline \multirow[b]{2}{*}{ Parametcrs } & \multicolumn{6}{|c|}{ Crude protein, $\mathrm{g} / \mathrm{kg} \mathrm{DM}$} \\
\hline & $18^{\mathrm{a}}$ & $68^{\mathrm{a}}$ & $98^{a}$ & $119^{\mathrm{b}}$ & $156^{\mathrm{c}}$ & $159^{d}$ \\
\hline \multicolumn{7}{|l|}{ Intake } \\
\hline $\mathrm{DM} g /\left(\mathrm{kgW}^{0.75} / \mathrm{d}\right)$ & 35.2 & 49.4 & 40.8 & 64.3 & 54.9 & 87.4 \\
\hline 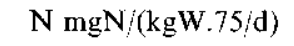 & 101 & 537 & 640 & 1224 & 1371 & 2223 \\
\hline \multicolumn{7}{|c|}{ 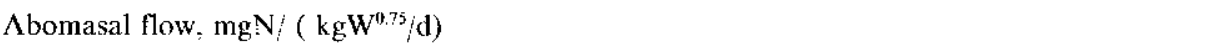 } \\
\hline total $N(\mathbf{l})$ & 332 & 677 & 598 & 796 & 691 & 2444 \\
\hline predicted EPN & 141 & 199 & 164 & 259 & 221 & 351 \\
\hline EPN/TN, \% & 42.5 & 29.4 & 27.4 & 32.5 & 32.0 & 14.4 \\
\hline \multicolumn{7}{|c|}{ Ileal now, mgN/ $\left(\mathrm{kgW}^{0.75} / \mathrm{d}\right)$} \\
\hline total $\mathrm{N}(\mathrm{TN})$ & 128 & 247 & 223 & - & $230^{\mathrm{e}}$ & 804 \\
\hline predicted EPN & 84 & 119 & 98 & - & 102 & 210 \\
\hline EPN/TN, \% & 65.6 & 48.2 & 43.9 & - & 44.3 & 26.1 \\
\hline \multicolumn{7}{|c|}{ Rectal flow, $23 \mathrm{mgN} /\left(\mathrm{kgW}^{0.75} / \mathrm{d}\right)$} \\
\hline total $N(T N)$ & 133 & 223 & 177 & 312 & 278 & 753 \\
\hline predicted EPN & 122 & 171 & 142 & 223 & 190 & 303 \\
\hline EPN/TN, \% & 91.7 & 76.7 & 80.2 & 71.5 & 68.3 & 40.2 \\
\hline
\end{tabular}

" from treatments $\Lambda, B$ and $C$ of Oliveira (1990), respectively

${ }^{b}$ mean values from treatments 1 and 2 of Matos (1991)

' mean values from treatments 3 and 4 of Matos (1991) and treatment D of Oliveira (1990)

d mean values from both treatments of Cecava et al. (1990)

${ }^{\mathrm{e}}$ from treatment $\mathrm{D}$ of Oliveira (1990)

\section{DISCUSSION}

The model performance was evaluated only partially, because of lack of independent information on endogenous protein losses in the literature, especially for cattle. However, further tests could be done as soon as adcquate expcrimental data become available. Keeping these restrictions in mind, the model behaviour seems to be satisfactory within the typical range of dietary conditions used in the present test.

In general, proportion of endogenous-protein $\mathrm{N}$ in the total $\mathrm{N}$ flow at all sites decreased as $\mathrm{CP}$ content of the diet and $\mathrm{N}$ intake increased. At the abomasum, this proportion decreased from 43 to $14 \%$ as protein content of the diet increased from 18 to $159 \mathrm{~g} / \mathrm{kg} \mathrm{DM}$. Daily flows of EPN at this site varied from 141 to 351 $\operatorname{mg~N} /\left(\mathrm{kg} \mathrm{W}^{0.75} / \mathrm{d}\right)$, a range below that reported by Hart and Leibholz (1990) for 
steers (i.e., 243 to $415 \mathrm{mg} / \mathrm{kg} \mathrm{W}^{0.75} / \mathrm{d}$ ) fed different amounts of low-degradable $\mathrm{N}$ diets and subjected to infusion of ${ }^{15} \mathrm{~N}$. However, these values are still higher when compared to the range from 30 to $87 \mathrm{mg} \mathrm{N}$ observed by Ørskov et al. (1986), using intragastric nutrition with VFA infused into the rumen of fistulated steers. Probably, this difference is due to the different techniques used in these studies. With a lack of solid food in the intragastric nutrition technique, EPN originating from sloughing of ruminally epithelial cells is reduced leading to an underestimation of EPN flows in fed animals.

At the ileum, the proportion of EPN in the total $\mathrm{N}$ flow decreased linearly from 66 to $26 \%$ (Table 2) as dietary CP rose from 18 to $159 \mathrm{~g} / \mathrm{kg} \mathrm{DM}$, with daily outflows varying from 84 to $210 \mathrm{mg} \mathrm{EPN} /\left(\mathrm{kg} \mathrm{W}^{0.75} / \mathrm{d}\right)$. This range of values lies within the range of mean values (i.e., $4710270 \mathrm{mg}$ ) reported in the literature (Salter and Smith, 1977; Tas et al., 1981; van Bruchem et al., 1985b, 1989; Valadares Filho et a1., 1990), for sheep and cattle using different techniques.

The proportion of EPN in the total $\mathrm{N}$ flow at the rectum decreased from 92 to $40 \%$ as CP content of the diet varied from 18 to $159 \mathrm{~g} / \mathrm{kg} \mathrm{DM}$ (Table 2). Daily flows of EPN at the rectum, varying from 122 to $303 \mathrm{mg} \mathrm{N} /\left(\mathrm{kg} \mathrm{W}^{0.75} / \mathrm{d}\right)$, are within the range of mean values for EFN (94 to $424 \mathrm{mg}$ ) reported in the literature for sheep and goats ( $A$ nderson and Lamb, 1967; Hogan and Weston, 1968; Mason, 1969, 1981; Brun-Bellut et al., 1987; Giger-Reverdin et al., 1991). Proportion of EPN in the total $\mathrm{N}$ flow at this site was consistently greater than those at the other sites, at all levels of dietary CP. This is the result of a lack of degradation and absorption in previous compartments, as well as of an extensive incorporation of EPN by caecal bacteria and their subsequent excretion in the faeces.

The significance of endogenous proteins as important sources of $\mathrm{N}$ recycling can be illustrated as follows. A typical Holstein-Friesian x Zebu dairy cow (500 $\mathrm{kg}$ live weight producing $10 \mathrm{~kg} / \mathrm{d}$ of fat-corrected milk $(\mathrm{FCM})$ ) requires a total of $202 \mathrm{~g} \mathrm{~N} / \mathrm{d}$ (NRC, 1989). According to the model, and using an average diet for dairy cows with $160 \mathrm{~g} \mathrm{CP} / \mathrm{kg} \mathrm{DM}, 37 \mathrm{~g} \mathrm{EPN} / \mathrm{d}$ would be available for absorption in the small intestine. This represents almost $20 \%$ of the total $\mathrm{N}$ required by this cow and may supply $\mathrm{N}$ for $2.6 \mathrm{~kg}$ of milk, that is, $25 \%$ of the cow's production. On the other hand, a typical Holstcin-Fricsian cow $(650 \mathrm{~kg}$ live weight and FCM production of $25 \mathrm{~kg} / \mathrm{d}$ ) requires $428 \mathrm{~g} \mathrm{~N} / \mathrm{d}$ and would have $45 \mathrm{~g} \mathrm{EPN} / \mathrm{d}$ available in the small intestine. This corresponds to only $10 \%$ of the total $\mathrm{N}$ requirement and may supply $\mathrm{N}$ for $13 \%$ of the cow's milk production. Thereforc, endogenous-protein sources appear more significant for milk production when a dairy cow of low- to medium-genetic merit is submitted to a low- $\mathrm{N}$ diet, a very common situation in most developing countries and tropical environments. On an extremely low-protein diet (i.e., less than $20 \mathrm{~g} \mathrm{CP} / \mathrm{kg} \mathrm{DM}$ ), endogenous sources may represent nearly 43,66 and $92 \%$ of the $\mathrm{N}$ in the abomasal, ileal and faecal contents (Table 2), respectively. However, sheep fed good quality diets 
based on ingredients obtained from plants grown under temperate climatic conditions showed higher EPN losses than did diets based on poor quality crop residues (Tamminga et al., 1995). The present model does not include such a compensation in EPN secretion in relation to diet quality and the high predicted figures for low-protein diets may be overestimated.

Another implication of EPN estimates to the protein nutrition is quoted by Satter and Dhiman (1995) when compared the American (NRC, 1989) and the British (AFRC, 1992) standard feeding systems for a high yielding dairy cow. They assumed a typical diet for a non-pregnant $600-\mathrm{kg}$ cow gaining $0.33 \mathrm{~kg}$ weight $/ \mathrm{d}$, producing milk with $40 \mathrm{~g}$ butterfat and $32 \mathrm{~g}$ protein per $\mathrm{kg}$, and consuming a daily ration of $18 \mathrm{~kg}$ DM. Predictions of actual milk yield based on energy calculation were nearly $26 \mathrm{~kg}$ milk/day in both systems. However, when predictions were based on protein calculation milk yields were 29 and $19 \mathrm{~kg} / \mathrm{day}$ with AFRC and NRC systems, respectively. According to the authors, the reason for this large discrepance is that the NRC has a much higher protein allowance for maintenance. Considering metabolic faecal $\mathrm{N}$ as part of the protein requirement, the $\mathrm{NRC}$ system assumes this requirement to equal $90 \mathrm{~g}$ absorbed protein per $\mathrm{kg}$ indigestible dry matter in the faeces, which results in a larger amount of $\mathrm{N}$ bcing discounted from the dietary protein, remaining less protein for milk production.

Dijkstra et al. (1996) have developed a simulation model for digestion kinetics in cattle fed sugar cane diets. However, the model was unable to accurately predict duodenal $\mathrm{N}$ flow. As stated by the authors, this may indicate the need for accommodating EPN sources in the model. Based on data in the literature, the present model seems to be able to estimate EPN flows at different sites of the GIT and can be used as a submodel for a more comprehensive mathematical model of nutrient kinetics in ruminants, such as that described by Neal et al. (1993) and Dijkstra et al. (1996).

Additionally, the model itself may be used to increase knowledge on $\mathrm{N}$ recycling as well as to improve estimation of maintenance requirement and of true digestibility of feed protein. In this context, further refinements of critical parameters may be necessary, especially in relation to the rate of EPN secretions and sloughing of the gut epithelial cells. In the current version, the model considers the secretion rate based only on DMI, and improvements can be made by including factors related to diet quality, such as: non-protein digestiblc dry matter or degradable fibre contents (Mason, 1984; van Bruchem et al., 1989; Żebrowska and Kowalczyk, 1991; Tamminga et al., 1995). Furthermore, understanding the total production of EPN and its subsequent re-absorption will need detailed information on scveral types of endogenous protein, such as, cnzymes, bile salts, mucus, and sloughed epithelial cells, which may differ largely in terms of degradation and passage. 


\section{Implicatons}

This study indicates that endogenous proteins may account for up to $43 \%$ of the duodenal NAN flow and, in many cases, these sources should play a significant role in the animal protein nutrition. The model itself can contribute to improved understanding of $\mathrm{N}$ recycling and endogenous protein losses, and thus, to assess maintenance requirements and digestibility of feed proteins more accurately. Further improvements in the model may be necessary, but these refinements will be possible only when some critical experimental data become available.

\section{REFERENCES}

Anderson M.J., Lamb R.C., 1967. Predicting digestible protein from crude protein. J. Anim. Sci. 26, 912-913 (Abstr.)

AFRC, 1992. Nutritive requirements of ruminant animals: Protein. Nutr. Abstr. Rev. 62, 787-835

Assis A.G., Campos O.F., Veira D.M., France J., Neal H.D.St.C., Aroeira L.J.M., 1993. Modelling endogenous protein flow in the ruminant gastrointestinal tract. J. Anim. Sci., Suppl. 1, 269 (Abstr.)

Brun-Bellut J., Blanchart G., Laurent F., Vignon B., 1987. Nitrogen requirements for goats. In: O.P. Santana, A.G. Silva, W.C. Foote (Editors). Proceedings of 4th International Conference on Goats. EMBRAPA/DDT, Brasilia, DF (Brazil), pp. 1205-1228

Cecava M.J., Merchen N.R., Berger L.L., Anderson D.R., 1990. Effect of energy level and feeding frequency on site of digestion and postruminal nutrient flows in steers. J. Dairy Sci. 73, 2470-2479

Dijkstra J., France J., Neal H.D.St.C., Assis A.G., Aroeira L.J.M., Campos O.F., 1996. Simulation of digestion in cattle fed sugar cane: model development. J.Agric. Sci., Camb. 127, 231-246

Dixon R.M., Nolan J.V., 1982. Studies of the large intestine of sheep. 1. Fermentation and absorption in sections of the large intestine. Brit. J. Nutr. 47, 289-300

Dixon R.M., Nolan J.V., 1983. Studies of the large intestine of sheep. 3. Nitrogen kinetics in sheep given chopped lucerne (Medicago sativa) hay. Brit. J. Nutr. 50, 757-768

Egan A.R., Boda K., Varady J., 1986. Regulation of nitrogen metabolism and recycling. In: L.P. Milligan, W.I. Grovum, A. Dobson (Editors). Control of digestion and metabolism in ruminants. Prentice-IIall, Englewood Cliffs, NJ, pp. 386-402

Giger-Reverdin S., Sauvant D., Hervieu J., Dorleans M.. 1991. Fecal and urinary nitrogen losses as influcneed by the dict carbohydratc and protein fractions in goats. In: B.O. Eggum, S. Boisen, C. Bersting, A. Danfacr, T. Hvelplund (Editors). Protcin metabolism and nutrition. Foulum (Denmark), pp. 358-360

Hart F.J., Leibholz J., 1990. A note on the flow of endogenous protein to the omasum and abomasum of stecrs. Anim. Prod. 51, 217-219

Hogan J.P., Weston R.H., 1968. Digestion of protein in the intestines of the sheep. Proc. Aust. Soc. Anim. Prod. 7, 364-368

IBM, 1975. Continuous System Modeling Program UU (CSMP 1U): Program reference manual. 4th Edtion, International Business Machincs Corporation, Program number 5734-XS9 
Jansen D.M., Dierkx R.T., van Laar H.H., Alagos M.J., 1988. PCSMP on IBM PC-AT's or PC-XT's and compatibles. Simulation Report CABO-TT nr. 15. Centre for Agrobiological Research (CABO) /Department of Theoretical Production Ecology. Agricultural Lniversity, Wageningen, The Netherlands

Kennedy P.M., Milligan L.P., 1980. Input of endogenous protein into the forestomachs of sheep. Can. J. Anim. Sci. 60, 1029-1032

MacRae J.C., Milne J.A., Wilson S., Spence A.M., 1979. Nitrogen digestion in sheep given poor-quality indigenous hill herbages. Brit. J. Nutr. 42, 525-534

Mason V.C., 1969. Some observations on the distribution and origin of nitrogen in sheep faeces. J. Agric. Sci, Camb. 73, 99-111

Mason V.C., 1981. Factors influencing faccal nitrogen excretion in shecp. 1. The digestibility and level of intake of pelleted diets. Z. Tierphysiol., Tierernähr., Futtermittelk. 45, 161-173

Mason V.C., 1984. Metabolism of nitrogenous compounds in the large gut. Proc. Nutr. Soc. 43, 45-53

Matos N.J.M., 1991. Niveis de ingestão de alimentos e de uréia sobre alguns parâmetros ruminais e digestão total e parcial em bovinos alimentados com dieta à base de cana-de-açúcar e uréia suplementada com farelo de arroz. Doctoral Thesis. Univ. Federal de Viçosa, MG, Brazil

NRC, 1989. Nutrient Requirements of Dairy Catte. National Academic Press, Washington, DC

Neal H.D.St.C., France J., Assis A.G., Aroeira L.J.M., Campos O.F., 1993. Supplementation of sugar cane diets for Brazilian dairy cattle: a modelling study. In: M. Gill, E. Owen, G.E. Pollot, T.L.J. Lawrence (Editros). Animal production in developing countries. BSAP Occasional Publ. No.16. British Society of Animal Production, Penicuik, Midlothian (UK), pp. 161-162

O'Connor J.D., Robinson P.H., Sniffen C.J., Allen M.S., 1984. A gastro-intestinal tract simulation model of digesta flow in ruminants. In: P.M. Kennedy (Editor). Techniques in particle size analysis of feed and digesta in ruminants. Canadian Society of Animal Science, Edmonton, Alberta (Canada), pp. 102-122

Oliveira W.H., 1990. Digestibilidade aparente e partiçoã da digestão da cana-de-açúcar adicionada de niveis crescentes de uréia. M.S. Thesis. Univ. Federal de Minas Gerais, Belo Horizonte, MG, Brazil

Qrskov E.R., Macleod N.A., Kyle D.I., 1986. Flow of nitrogen from the rumen and abomasum in cattle and sheep given protein-free nutrients by intragastric infusion. Brit. J. Nutr. 56, 241-248

Salter D.N., Smith R.H., 1977. Digestibilities of nitrogen compounds in rumen bacteria and in other components of digesta in the small intestine of the young steer. Brit. J. Nutr. 38, 207-216

Satter L.D., Dhiman T.R., 1995. Protein and energy requirements and responses: a United State perspective. In: T.I.J. I awrence, F.J. Gordon, A. Carson (Fditors). Breeding and feeding the high genetic merit dairy cow. BS $\Lambda$ S Occasional Publ. No. 19. British Society of Animal Science, Penicuik. Midlothian (UK), pp. 43-50

Stallcup O.T., Davis G.V., Shiclds L.V., 1975. Influence of dry matter and nitrogen intakes on fecal nitrogen losses in cattle. J. Dairy Sci. 58, 1301-1307

Swanson E.W., 1982. Estimation of metabolic protein requirements to cover unavoidable losses of endogenous nitrogen in maintenance of cattle. In: F.N. Owens (Editor). Protein requirements for cattle. Oklahoma State University, Stillwater, pp. 183-197

Tamminga S., Schulze H., Van Bruchem J., Huisman J., 1995. The nutritional significance of endogenous N-losses along the gastro-intestinal tract of farm animals. Arch. Anim. Nutr. 48. 9-22

Jas M.V., Evans R.A., Axford R.F.E., 1981. The digestibility of amino acids in the small intestine of the sheep. Brit. J. Nutr. 45, $167-174$

Valadares Filho S.C., Silva J.F.C., Sant'Anna R., Leão M.I., Valadares R.F.D., Castro A.C.G., 1990. Composiçâo de bactérias ruminais e absorçào de amino ácidos microbianos no intestino delgado de novilhos holandeses, nelores c búfalos mestiços. Rev. Soc. Bras. Zoot. 19, 431-435 
Van Bruchem J., Bongers L.J.G.M., van Walsem J.D., Onck W., van Adrichem P.W.M., 1985 a. Digestion of proteins of varying degradability in shecp. 3. Apparent and truc digestibility in the small intestine and ileal endogenous flow of $\mathrm{N}$ and amino acids. Neth. J. Agric. Sci. 33, 285-295

Van Bruchem J., Bangma G.A., Lammers-Wienhoven S.C.W., van Adrichem P.W.M., 1985b. Digestion of non-microbial protein and amino acids in the small intestine of sheep as affected by peptic proteolysis in the abomasum. Z. Tierphysiol., Tierernähr., Futtermittelk. 54, 113-121

Van Bruchem J., Bongers L.J.G.M., Lammers-Wienhoven S.C.W., Bangma G.A., van Adrichem P.W.M., 1989. Apparent and true digestibility of protein and amino acids in the small intestine of sheep as related to the duodenal passage of protein and non-protein dry matter. Livest. Prod. Sci. 2, 317-327

Van Soest P.J., 1994. Nutritional Ecology of the Ruminant. 2nd Edition, Cornell University Press, Cornell NY

Voigt J., van Bruchem J., Lammers-Wienhoven T., Ketelaars J.J.M.H., Tamminga, S., 1994. Flow of endogenous protein along the small intestine of sheep - Effect of cell walls. Proc. Soc. Nutr. Physiol. 3, 104

Żebrowska T., Kowalczyk 3., 1991. Nitrogen secretion into isolated loops of the small intestine in conscious shecp. J. Anim. Physiol. Anim. Nutr. 65, 133-139

\section{STRESZCZENIE}

Model do szacowania przeplywu bialka endogennego w przewodzie pokarmowym preeżuwaczy

Opracowano model symulujący kinetykę azotu białka endogennego (EPN) w przewodzie pokarmowym przcżuwaczy. Przewód pokarmowy podzielono na trzy przedziały: żołądek, jelito cienkie $\mathrm{i}$ jelito grube. Model zawiera trzy pule EPN odpowiadajce tym przedzialom, stosując dwie możliwości dostarczania do nich endogennych związkow azolowych (sekrecja i dopływ) i ich odprowadzania z przedziałów (wchlanianie i wyplyw). Wartość odpowiednich parametrów ustalono na podstawic ostatnich danych z litcratury. Według przcwidywan modclu, udział EPN w ilości przepływającego azotu ogólnego wzrasta, gdy zawartość białka ogólnego w diccie i pobranie azotu zmniejsza się. Przy skarmianiu diet o ekstremalnie niskiej zawartości białka, EPN może osiągnąć wartości 43, 66 i 92\% azotu ogólnego w treści trawieńca, jelita biodrowego i kale, odpowiednio. Model może przyczynić się do poszerzenia wiedzy o recyrkulacji azotu, jak też do ok reślania strat bialka endogennego przy obliczaniu zapotrzebowania bytowego. 